\title{
EFFECTS OF HEAT STRESS ON PHYSIOLOGICAL TRAITS IN SHEEP
}

\author{
Çağrı Kandemir, Nedim Koşum, Turgay Taşkin \\ Ege University, Faculty of Agriculture, Department of Animal Science, \\ 35100 Bornova, Izmir, Türkiye \\ cagri.kandemir@ege.edu.tr
}

\begin{abstract}
Sheep husbandry in tropical and sub-tropical regions tends to breed throughout the year, although the sexual activity is restricted to a certain extent to the summer months. In such areas, a high ambient temperature is the major constraint on animal productivity. This effect is aggravated when heat stress is accompanied by high ambient humidity. Exposure of sheep to elevated temperatures results in a decrease of body weight, average daily gain, growth rate and body total solids. The possible mechanisms involved in inducing the biological changes in heat-stressed sheep could have definite applications. Growth in young animals, the increase in live body weight, is controlled genetically and environmentally. The available nutrients, hormones and enzymes, as well as, elevated ambient temperatures are considered as some of the environmental factors that can influence daily gain. During the early stage of embryonic life, the total cell number and placentome size were greatly reduced and the cell size only slightly decreased by exposure to warm temperatures, compared to thermo-neutral temperatures. This occurred at the time of examining aspects of placental protein and energy metabolism of pregnant ewes during middle and late gestation. The effect of heat is aggravated when heat stress is accompanied with high ambient humidity.
\end{abstract}

Key words: sheep; heat stress; welfare; milking management

\section{ЕФЕКТИТЕ НА ТОПЛОТНИОТ СТРЕС ВРЗ ФИЗИОЛОШКИТЕ ОСОБИНИ НА ОВЦИТЕ}

Во овчарството во тропските и суптропските региони има тенденција да се врши оплодување во текот на целата година, иако сексуалната активност е ограничена до одреден степен на летните месеци. Во таквите области високата температура е главна пречка за продуктивноста на животните. Овој ефект се влошува кога топлотниот стрес е придружен со висока амбиентална влажност. Изложеноста на овците на зголемени температури резултира со намалување на телесната тежина, просечниот дневен прираст, процентот на растежот и вкупната телесна маса. Можните механизми кои се вклучени во поттикнување на биолошки промени кај овците во топлите предели дефинитивно би можеле да се користат. Растежот на младите животни и зголемувањето на нивната телесна маса е контролирано генетски и од надворешната средина. Достапните хранливи материи, хормони и ензими, како и покачените температури на воздухот се сметаат за некои од еколошките фактори кои можат да влијаат врз дневниот прираст. При изложеност на високи температури вкупниот број на клетки и големината на плацентомот во фазата на ембрионалниот развој беа значително намалени, додека големината на клетките беше само малку намалена, во споредба со термо-неутрални температури. Тоа се случи при испитување на протеините на плацентата и енергетскиот метаболизам кај гравидни овци во средината и кон крајот на бременоста. Ефектот на топлината се влошува кога топлинскиот притисок е придружен со висока амбиентална влажност.

Клучни зборови: овци; топлотен стрес; благосостојба; менаџирање на молзење

\section{INTRODUCTION}

Studies on the heat stress and result of welfare in sheep have developed slowly, due to some of their physiological peculiarities and their preva- lent extensive production system. In fact, since sheep are considered very rustic animals, their ability to cope with prohibitive environmental conditions and inadequate management practices, without harming their welfare and productive per- 
formance, has been often overrated. In addition, the diffusion of extensive husbandry of sheep has led to the belief that sheep and goats did not need any welfare assessment. This was based on the fact that generally the highest standard of livestock wellbeing, associated with minimal behavioural restriction and man's intervention in the biological cycle of the animal, is attributed to the extensive production system. Sheep are mostly spread throughout internal and marginal areas, where breeders are still anchored to traditional production systems and are not receptive to updated husbandry techniques, especially to those without an immediate economic and tangible impact.

\section{EFFECT OF HEAT STRESS ON BODY WEIGHT}

Growth, the increase in live body mass or cell multiplication, is controlled genetically and environmentally. The available nutrients, hormones and enzymes, as well as, elevated ambient temperatures are considered as some of the environmental factors that can influence ADG (Hafez, 1991; Habeeb et al., 1997). Placental development requires adequate and organized interaction of vascular growth factors and their receptors - including a vascular endothelial growth factor and the placental growth factor. Exposure to environmental heat stress early in placental development, could impair normal placental vascular development due to lower levels in these tissues. During the early stage of embryonic life, the total cell number and the placentome size were greatly reduced and the cell size only slightly decreased by exposure to warm temperatures, compared to thermo-neutral temperatures. This occurred when environmental conditions, i.e. fetal and placental weights and total examining aspects of placental protein and energy metabolism of pregnant ewes during mid and late gestation. Regnault et al. (2000) additionally found that chronic heat exposure lowers the circulating placental hormone concentrations due to impaired trophoblast cell development. The impact of heat exposure during placental growth is big enough to restrict early fetal development, even before the maximum fetal growth phase. Soto et al. (1998), however, reported the main effect of heat stress over reproductive efficiency to be during the first 17 days of pregnancy and the use of shade to be beneficial to improve the pregnancy rate in a flock. Lamb birth weights of temperate sheep breeds show a linear decline when maintaining their dams for generations in hot, semi-arid locations. Such results give an idea regarding the level of tolerance of the mentioned temperate sheep breeds to the hot conditions. Lambing average daily gain values were recorded to be lower in summer than in winter in lambs, as well as in a psychrometric chamber (30$\left.40{ }^{\circ} \mathrm{C}\right)$ compared to a shelter $\left(20-30{ }^{\circ} \mathrm{C}\right)$, for Suffolk sheep (Marai et al., 2000; Padua et al., 1997). Similarly, body weight, growth rate, total body solids and body solids daily gain (g) were impaired following exposure to elevated temperatures (Ismail et al., 1995). The effects of elevated ambient temperature on growth performance are the product of a decrease in anabolic activity and the increase in tissue catabolism. This decrease in anabolism is essentially caused by a decrease in voluntary feed intake of essential nutrients. The decrease, especially metabolizable energy for both body maintenance and weight gain, causes a loss in the production per unit of feed. The increase in tissue catabolism occurs mainly in fat depots and/or lean body mass. The latter effect is due to the catabolism of endogenous DNA and RNA purines due to the increase in catacholamines and glucorticoids (Marai et al., 2000, 2006).

\section{FEED INTAKE AND UTILIZATION}

Sheep have a better ability to convert fibrous, low quality feedstuffs into meat and other products than cattle (Hafez, 1991). However, moderate heat stress reduces intake and growth in young sheep consuming a high feed intake of medium quality roughage diets. This does not affect the relative responses to supplements providing principally fermentable $\mathrm{ME}$ or a similar amount of fermentable ME and additional metabolizable protein (Dixon et al., 1999). Exposure to high ambient temperatures, augments the efforts to dissipate body heat, resulting in the increase of respiration rate, body temperature and consumption of water, and a decline in feed intake. A higher heat increment is caused by the specific dynamic action that accompanies the metabolism of feed which is highest in the case of poor quality, fibrous feedstuffs (Marai et al., 2000). Factors such as water deprivation, nutritional imbalance and nutritional deficiency may exacerbate the impact of the heat stress. Sheep, however, recorded a lower sensitivity to heat stress, when compared to cattle, at a 
maintenance feed level. The provision of shade shelter is suggested as a practical measure applicable under extensive conditions (Silanikove-Nissim, 2000). Studies show dry matter intake to decrease significantly following exposure to heat stress in Croix, Karakul, Rambouillet, Sardinian and Comisana sheep (Nardon et al., 1991). Similarly, dry matter intake per kilogram live weight was lower and the maintenance requirements were higher at high ambient temperatures. The decrease in concentrate intake by rams was estimated to be approximately $13 \%$, without altering the roughage consumption, when kept at $35^{\circ} \mathrm{C}$ in a climatic chamber. The daily feed intake and feed conversion also significantly decreased in Suffolk lambs under hot conditions in a climatic chamber $(30.5$ $\left.{ }^{\circ} \mathrm{C}\right)$, compared to a group under shelter $\left(19.3{ }^{\circ} \mathrm{C}\right)$, during spring (Padua et al., 1997).

\section{GESTATION PERIOD}

Exposure of the pregnant ewe during mid and late gestation to warm ambient temperatures, greatly reduces the total embryo cell number and placentome size. In addition, lamb birth weight, live body weight gain or growth rate, as well as, the total body solids and daily solids gain are impaired by exposure to elevated temperatures. In other words, it can be stated that lamb production is deleteriously affected by exposure to heat stress and this causes an economic loss. The percentage loss pertaining to heat stress has been estimated in other species, to be more than $70 \%$ of live weight at weaning (Marai et al., 2006). Such phenomena necessitate either to protect the ewes from exposure to high ambient temperatures during the breeding season or to carry out breeding of ewes during the milder periods of the year, in the warm climate zones.

\section{ANIMAL WELFARE AND MILKING MANAGEMENT ON SHEEP}

Confined rearing is usually characterized by high stocking density and prolonged faeces accumulation in sheep housing. Therefore, adequate space allowance, careful litter management and scrupulous monitoring of the terms of temperature, relative humidity and air quality are crucial aspects in sheep housing. The minority of sheep and goat flocks are permanently housed, while most of them are housed only during the night and in periods in which grazing is not feasible. In any case, it is fundamental to understand that maintenance of good hygiene conditions, associated with correct dimensioning of structural parameters and adoption of proper management practices, is important in either type of system. Unfortunately, sheep often have shelters that are not appropriate, in terms of design, materials and size.

Milking management is a critical point in sheep farms. The time animals need to adapt to machine milking, pre-parturition training to milking parlour, the number of lambs born by ewes, and type of milking, can markedly affect the welfare, health and production performance of dairy sheep. The behaviour of animals in the milking parlour is probably influenced by both genetic factors and their previous handling experience. The stress caused by fear of humans has practical implications on dairy animal performance. Therefore, reducing the emotional or physical stress of dairy animals helps to increase their productivity and to maintain their health status. Two main mechanisms may be involved in the response of lactating animals to stress: a local mechanism, proposed by Silanikove et al. (2000), which connects the plasmin-plasminogen system to the autocrine inhibition of lactation, and a systemic mechanism which takes into account the role of the hypothalamicpituitary-adrenal axis(HPA) in determining the rate of milk secretion (Matteri et al., 2000). Silanikove et al. (2000) showed that stress activates the HPA axis that liberates cortisol into blood plasma. This in turn induces the liberation of the plasmin activator from the mammary epithelial cells into the mammary cistern, where it activates the plasmin system that degrades $\beta$-casein and produces the residue 1-28 $\beta$-casein. This is also called proteoso-peptone channel blocking (PPCB). PPCB inhibits the ion channels in mammary epithelia apical membranes and thus also inhibits lactose and monovalent ion secretion. This results in a decrease in milk volume. When injecting the 128 Bcasein fraction into the udder lumen of sheep, Pulina et al. (2005) observed a transient reduction in milk production, which was not associated with the disruption of the integrity of the mammary cell junctions. In the systemic mechanism, stress activates the HPA axis and stimulates the secretion of adrenocorticotropic hormone (ACTH) by the pituitary gland. The ACTH stimulates the synthesis and release of glucocorticoids from the adrenal cortex. Cortisol causes a decrease in milk synthesis by blocking the uptake of glucose by the mammary 
gland (Sevi et al. 2001, Dwyer et al., 2004). A secondary effect of stress is the inhibition of prolactin synthesis by the pituitary gland due to the hypothalamic release of dopamine. Both situations cause a transient metabolic energy surplus due to a reduction in the energy output by the milk and an increase in mobilization of stored energy. This is caused by a sharp increase in glucocorticoids, followed by an increase in insulin and adipose tissue uptake capacity. If the stress continues, it may have negative effects on lactation yield, especially in the second half of lactation, due to increased secretion of the leptin hormone by adipose tissue.

\section{EFFECTS OF BREAKDOWN OF THE MATERNAL BOND ON LAMB WELFARE}

Artificial rearing has not had great diffusion in sheep breeding. Apart from technical and management factors, the outcome of artificial rearing of lambs depends largely on the ability of the newborn to readily adapt to the artificial teat (Sevi et al., 2006). During the transition from maternal milk to artificial rearing, emotional and nutritional stresses of young animals have deleterious effects on their growth, health and vitality. Such stresses are caused by the breakdown of the mother/young bond and by inadequate substitution of sheep milk, which is nutritionally much richer than commercial milk replacer. The recent introduction of the so-called acid milk replacers on the market solves a number of technical problems, but tends to sharpen the nutritional stress of the lamb due to their lower fat and protein contents compared to traditional milk replacers. When the transition to artificial rearing is abrupt, it is necessary to use strategies which help lambs to have a fast and positive approach to the artificial teat. This is important because of at least three reasons: firstly, lack of adaptation to artificial rearing can have deleterious effects on growth and survival of newborn animals; secondly, the presence of longlasting stress conditions can lead to a reduction of immune function; and thirdly, the more difficult the approach to artificial rearing is, the more compromised is the ability of young animals to face other stressful situations, even transitory ones. Previous studies have highlighted that, even after an early separation of lambs from their mothers, a gradual transition over a 10-day period, from maternal milk to milk replacer can improve the welfare of the artificially reared lamb, even if it does not allow it to reach the same growth rate of the dam suckled lamb (Sevi et al., 1999a,b). On the contrary, keeping the lamb with the mother, thus giving it all maternal stimuli (touch, vocal, smell and sight), but hindering its access to the mother udder, does not improve the well-being of the lamb. Instead, such deprivation from natural suckling frustrates the lamb, probably because of non satisfaction of its social and nutritional expectations (Napolitano et al., 2003). A useful tool to minimize the stress related to artificial rearing is gentling. In fact, several studies (Boivin et al., 2001; Caroprese et al., 2006) have highlighted that gentling strongly encourages the lambs reared without their mothers to positively interact with the stockman, whereas gentling has no beneficial effects on dam-reared animals. In artificially reared lambs, gentling improves their immune reactivity, making it comparable to that of damsuckled lambs, and reduces their plasma cortisol responses to handling. Peer rearing, mainly in the presence of older and more expert lambs, can also be greatly beneficial, by minimizing the stress related to lamb separation from the mother and by stimulating an adequate behaviour of the artificially reared lamb (Casamassima et al., 2001).

\section{CONCLUSIONS}

Field trials have clearly demonstrated that even if sheep are considered to be very rustic, they can greatly benefit from careful flock management, which can markedly improve their wellbeing and biological efficiency. Extensive husbandry has proved to be beneficial to the welfare needs of lactating ewes, but exposure to climatic extremes, seasonal fluctuations of herbage quality and quantity, and parasitism can threaten the welfare of extensively reared flocks. Under semi-intensive farming conditions, instead, sheep are generally preserved from hunger and thirst, and are sheltered from climatic extremes, but they live in a very predictable and less motivating environment. In semi-intensive rearing much attention must be given to the micro-environment control, and to the choice of proper house structures, material and design, in order to avoid crowding, aggressive behaviour, increased ambient pollution, and poor udder health. Irrespective of rearing system, proper timing, careful control of sanitation of milking operations and adoption of correct technical parameters of milking machines are also important for 
sheep welfare. For all these reasons the farmer and the stockmen play a major role in semi-intensive and extensive rearing.

\section{REFERENCES}

[1] Boivin, X., Nowak, R., Terrazas Garcia, A. (2001), The presence of the dam affects the efficiency of gentling and feeding on the early establishment of the stockpersonlamb relationship. Appl. Anim. Behav. Sci. 72, 89-103.

[2] Caroprese, M., Albenzio, M., Annicchiarico, G., Sevi, A. (2006): Changes occurring in immune responsiveness of single and twin bearing Comisana ewes during the transition period. J. Dairy Sci. 89, 562-568.

[3] Casamassima, D., Sevi, A., Palazzo, M., Ramacciato, R., Colella, G. E., Bellitti, A. (2001): Effects of two different housing systems on behavior, physiology and milk yield of Comisana ewes. Small Ruminant Res. 41, 151-161.

[4] Dixon, R. M., Thomas, R., Holmes, J. H. G. (1999): Interactions between heat stress and nutrition in sheep fed roughage diets. J. Agric. Sci. 132 (3), 351-359.

[5] Dwyer, C. M., Bornett, H. L. (2004): Chronic stress in sheep: assessment tools and their use in different management conditions. Anim.Welfare, 13, 293-304.

[6] Habeeb, A. A., Marai, I. F. M., Kamal, T. H., Owen J. B. (1997): Genetic improvement of livestock for heat adaptation in hot climates. In: Proceedings of International Conference on Animal, Poultry and Rabbit Production \& Health, Dokki, Cairo, Egypt, pp. 11-16.

[7] Hafez, E. S. E. (1991), Reproduction in Farm Animals, Fifth ed. LEA \&Febiger, Philadelphia.

[8] Ismail, E., Abdel-Latif, H., Hassan, G. A., Salem, M. H. (1995): Water metabolism and requirements of sheep as affected by breed and season. World Rev. Anim. Prod. 30 (1-2), 95-105.

[9] Marai, I. F. M., Bahgat, L. B., Shalaby, T. H., AbdelHafez, M. A. (2000): Fattening performance, some behavioural traits and physiological reactions of male lambs fed concentrates mixture alone with or without natural clay, under hot summer of Egypt. Ann. Arid Zone. 39 (4), 449-460.

[10] Marai, I. F. M., El-Darawany, A. A., Abou-Fandoud, E. I., Abdel-Hafez, M. A. M. (2006): Serum blood components during pre-oestrus, oestru and pregnancy phases in Egyptian Suffolk as affected by heat stress, under the conditions of Egypt. Egypt. J. Sheep Goats Desert Anim. Sci., 1 (1), 47-62.

[11] Matteri, R. L., Carroll, J. A., Dyer, C. J. (2000): Neuroendocrine responses to stress. In: G. P. Moberg and J. A. Mench (eds.) The Biology of Stress: Basic Principles and
Implications for Animal Welfare. CAB International, Wallingford, Oxon, UK, pp 43-76.

[12] Napolitano, F., Annicchiarico, G., Caroprese M., De Rosa, G., Taibi, L., Sevi, A. (2003): Lambs prevented from suckling their mothers display behavioral, immune and endocrine disturbances. Physiol. Behav., 78, 81-89.

[13] Nardon, A., Ronchi, B., Valentini, A. (1991): Effects of solar radiation on water and food intake and weight gain in Sarda and Comisana female lambs. In: Animal Husbandry in Warm Climates, Vol. 55. EAAP Publication, pp. 149-150.

[14] Padua, J. T., Dasilva, R. G., Bottcher, R. W., Hoff, S. J. (1997): Effect of high environmental temperature on weight gain and food intake of Suffolk lambs reared in a tropical environment. In: Proceedings of 5th International Symposium, Bloomington, Minnesota, USA, pp. 809-815.

[15] Pulina, G., Mazzette, A., Battacone, G., Nudda, A. (2006): Feed restriction alters milk production traits in Sarda dairy ewes. J. Dairy Sci., 89 (Suppl. 1), 59 (abstr.).

[16] Regnault, T. R. H., Orbus, R. J., Battaglia, F. C., Wilkening, R. B., Anthony, R. V. (2000): Altered arterial oncentrations of placental hormones during maximal placental growth in a model of placental insufficiency. J. Endocrinol., 162 (3), 433-442.

[17] Sevi, A., Albenzio, M., Annicchiarico, G., Caroprese, M., Marino, R., Santillo, A. (2006): Effects of dietary protein level on ewe milk yield and nitrogen utilization, and on air quality under different ventilation rates. J. Dairy Res., 73, 197-206.

[18] Sevi, A., Massa, S., Annicchiarico, G., Dell'Aquila, S., Muscio, A. (1999a): Effect of stocking density on ewes milk yield and incidence of subclinical mastitis. J. Dairy Res., 66, 489-499.

[19] Sevi, A., Napolitano, F., Casamassima, D., Annicchiarico, G., Quarantelli, T., De Paola, R. (1999b): Effect of a gradual transition from maternal to reconstituted milk on behavioural, immune and endocrine responses of lambs. Appl. Anim. Behav. Sci., 64, 249-259.

[20] Sevi, A., Taibi, L., Albenzio, M., Muscio, A., Dell'Aquila, S., Napolitano, F. (2001): Behavioral, adrenal, immune, and productive responses of lactating ewes to regrouping and relocation. J. Anim. Sci., 79, 1457-1465.

[21] Silanikove, Nissim (2000): Effects of heat stress on the welfare of extensively managed domestic ruminants. Livest. Prod. Sci., 67 (1-2), 1-18.

[22] Soto, A., Draghi, G., Boyezuk, D., Soni, C., Nigro, H., Cetra, B., DeLa-Sota, R. L. (1998): Use of shade during the breeding season to reduce heart stress and to increase the overall flock pregnancy rate in a subtropical environment. Rev. Brasileira Reprod. Anim., 22 (2), 97-101. 